\title{
AGRICULTURAL FINANCE AND ECONOMIC GROWTH: EVIDENCE FROM NIGERIA
}

\author{
Funso Abiodun OKUNLOLA ${ }^{1}$, Godswill Osagie OSUMA ${ }^{2}$, Ehimare Alexander OMANKHANLEN ${ }^{3}$
}

\author{
Department of Banking and Finance, Covenant University \\ E-mails: ${ }^{1}$ abiodun.okunlola@stu.cu.edu.ng; ${ }^{2}$ godswill.osuma@covenantuniversity.edu.ng (corresponding author); \\ 3alexander.omankhanlen@covenantuniversity.edu.ng
}

Received 14 March 2019; accepted 06 August 2019

\begin{abstract}
The study performed an in-depth examination of the impact of guaranteed agricultural finance to oil palm, cocoa, groundnuts, fishery, poultry, cattle, roots, and tubers on the real gross domestic product of the country. Time series data was sourced from the Central Bank of Nigeria statistical bulletin of various issues. The data sets covered thirty-seven (37) years spanning from 1981 to 2017. The study used Autoregressive Distributed Lag (ARDL) model for its analysis. However, prior estimation and due to several exogenous variables, Phillip Perron stationarity test was used to determine the order of integration because of its robustness to serial correlation and heteroskedasticity. The study also specified the lag criterion based on LR, FPE, AIC, SC, and HQ using Newey-West covariance matrix estimator. Findings from both short-run and long-run models as confirmed by the Wald test, which shows that none of the guaranteed agricultural finance is statistically significant to real gross domestic product. The study, therefore, recommends increased funding and deliberate efforts at determining which of the nominated agricultural spending has the most contributory impact on growth.
\end{abstract}

Keywords: agriculture, finance, real gross domestic product, Phillip Perron, Wald Test, autoregressive distributed lag.

JEL Classification: Q14, Q18, P32.

\section{Introduction}

The agricultural sector has the potential to stimulate and/ or expedite economic growth which could lead to economic development in the long run. Thus, intervention funds should be deployed to finance the agricultural sector in other to regain our export dominance of various agricultural products such as; cotton, cocoa, groundnut, and palm oil e.tc which would support the need for raw materials by our industrial and or manufacturing sector. Indeed the economy of scale witnessed in the early beginnings of our nations' post-independence (i.e. after 1960), which was anchored on agricultural production has not been re-examined in spite of the continuously guaranteed finances made available (Okunlola, 2013, 2014, Okunlola and Oke 2018).

The agricultural sector was the mainstay of the Nigerian economy before the discovery of crude oil at Oloibiri oilfield on January $15^{\text {th }}, 1956$. This led to an increased financing of the oil sector and a decreased financing on the agricultural sector thereby, leading to a drastic reduction in our agricultural produce and export which nosedived to the demise of our manufacturing sectors due to lack of raw materials hence, the high unemployment rate leading to various crimes experienced in the country. As a result of the significant contribution of the Micro, Small, and Medium Enterprise (MSME) to the growth of the Nigerian economy, two hundred and twenty billion naira ( $\$ 220,000,000,000$ ) share capital was launched by the Central Bank of Nigeria (CBN) on August $15^{\text {th }}, 2013$ to help in financing MSMEs that are linked with the agricultural and manufacturing sectors. Thus, boosting financial activities in the agricultural sector which would help reduce the effects of the global decline in oil price experienced in the country (Osuma et al. 2019). Thus, after this introduction, the next section is the review of various piece of literature, followed by the

Copyright $\odot 2019$ The Authors. Published by VGTU Press.

This is an Open Access article distributed under the terms of the Creative Commons Attribution License (http://creativecommons.org/licenses/by/4.0/), which permits unrestricted use, distribution, and reproduction in any medium, provided the original author and source are credited.. 
methodology, findings, and discussion, conclusion, recommendations, acknowledgment and references.

\section{Literature review}

Adesina et al. (2006) posited that agricultural finance promotes a sustainable economy, reduces poverty, increases business opportunities and leads to economic growth that improves the standard of living of the people. Omankhanlen (2013) averred that the lack of agricultural credit to finance agrarian investment is a major problem in mechanizing our agricultural produce. Oyakhilomen and Zibah (2014), examined Agricultural production output and its effects on economic growth in Nigeria considering the rural poverty alleviation. They also used the autoregressive distributed lag (ARDL) bound test approach for their analysis. They found that agricultural production significantly influences economic growth positively in Nigeria. They further opined that irrespective of economic growth, poverty is still on the increase in the country. They recommended that the Nigerian economy should be diversified from being a mono-economy that depends majorly in crude oil to an agrarian-based economy which would birth schemes to help alleviate poverty, especially at the grass-root level.

Oboh and Ekpebu (2011) made use of ordinary least square (OLS) to determine the financial allocation to the agricultural sector. They found that there is a pertinent need to re-access the Nigerian Agricultural, Cooperative and Rural Development Bank (NACRDB) factors for allocating credits to beneficiaries. Ewetan et al. (2017) empirically examined the long-run relationship between agricultural output and economic growth in Nigeria using time series data from 1981 to 2014. They found from their co-integration test and vector error correction model (VECM) that there exists a long-run relationship between agricultural output and economic growth which resonated with the results of their Granger causality test indicating a causality between agricultural output and economic growth in Nigeria. They further stressed the importance of government funding's, adequate storage amenities and easy access to the agricultural products (good road networks) in other not to make the work too laborious to engender more participation in the sector. Banks are the key agents of fund disbursements to the agricultural sector, but some banks prefer lending funds based on the anticipated income of their customer's especially when it has to do with microlending as they are highly risk-averse with agro-financing (Osuma et al. 2018). This alone has discouraged banks (be it deposit money banks, Microfinance banks, Agricultural banks e.tc) from lending to small and peasant farmers who make up a large proportion of farmers in Nigeria. Obansa and Maduekwe (2013) opined that agricultural finance is anchored on long term financing aimed at inducing agricultural spurred growth within the economy. They further stated that long term financing of agriculture would help instigate massive agricultural investments and fast adoption of technologies necessary to spur economic growth through agro-finance. Hartarska et al. (2015) averred that alleviating credit constraints in agriculture is very crucial. Some of the concerted efforts to finance the agricultural sector have rarely produced any form of improvement. Ayeomoni and Aladejana (2016) examined the relationship between agricultural credit and economic growth taking Nigeria as the case study and they found that there exists a short and long-run relationship between agricultural credit and economic growth. They also posited that the importance of the agricultural sector in a country cannot be overemphasized because it has and will continue to be the source of feeding to the populace at large and also a veritable source of income to aid economic development. Agriculture is the foundation of poverty alleviation, economic growth, and development. Which makes the battle for a nations strategic economic growth to be either won or lost based on how it manages its agricultural sector hence, the more budgetary allocation should be made to the agricultural sector (Omorokunwa and Obadiaru 2016, Sertoğlu et al. 2017).

The political administration of the country has changed hands over the years and this has led to the establishment of one pilot program or the other that seeks to improve agricultural development in the country (Ijaiya et al. 2016, Okunlola and Oke 2018). From post-independence, the establishment of the Nigeria Research Institute in 1960 1964, the Agricultural Research Council of Nigeria in 1971, National Accelerated Food Production Project (NAFPP) launched in 1972, Integrated Agriculture Development Projects; Nigerian Agriculture and Cooperative Bank in 1973. Specialized Marketing Boards in 1975 to fix commodity prices and the establishment of The National Grains and Roots Cultivation in 1975 to accelerate production of grains and roots and crops in Nigeria. The Operation Feed the Nation (OFN) aimed at mobilizing members of the public to participate in agricultural production, River Basin Development Authorities in 1976; the Agriculture Credit Guarantee Scheme Fund (ACGSF) and Rural Banking Scheme in 1977. There is also the Land Reform of 1978 that seeks to make land available for agricultural purposes. We also have the Green Revolution Programme inaugurated in 1980 meant to increase agricultural produce; the Directorate for Foods, Roads and Rural Infrastructure (DEFRI) by the Babangida lead administration meant to promote rural development, which later merged with the Federal Ministry of Water Resources in 1993. There is the existence of Vision 20:2020 and the NEEDS programmes when the country returned to civil rule in 1999, the Maputo declaration of 2003 and the Economic Recovery Growth Plan (ERGP) of the present administration which seek to 
diversify the economy with the mantra of agricultural economy (Okunlola and Oke 2018, Okunlola 2014, Omilola and Lambert 2009, Manyong et al. 2003). Isibor et al. (2018) opined that from the year 2000 to 2007 , agricultural sector in Nigeria contributed 7.4 percent (\%) to our GDP and it advanced from 23.96 percent $(\%)$ in the fourth quarter (Q4) of 2014 to 23.86 percent (\%) to 24.18 percent in the fourth month of 2016.

\section{Methodology}

Extensive path to achieving a more robust methodology depth has been employed in this study. Specifically, for robust treatment applied to serial correlation and heteroskedasticity, the study uses the Phillips Peron (PP) Unit root testing to determine the level of stationarity of the series. This was also confirmed through other tests by determining the series lag selection criterion, model diagnostics, model stability, Wald test, the cumulative sum CUSUM test, and error correction term (ECM) in the path to estimating the Autoregressive distributed lag (ARDL). The study methodology is premised on that of Ayeomoni and Aladejana (2016), Onoja et al. (2017). Data for the series is time series consisting of real values of agricultural credit guaranteed provision to oil palm (OP), cocoa, groundnuts (Gnts), fishery, poultry, cattle, and roots and tubers as the independent variables; while inflation deflated real gross domestic product (RGDP) is used and serves as the dependent variable. Data covers thirty-seven (37) years (i.e. 1981-2017) and it is sourced from Central Bank of Nigeria statistical bulletin of various issues. Analysis aid is through E-views statistical software.

\subsection{Model Specification and Estimation Process}

\subsubsection{Phillip Perron Unit Root Test}

The study estimated the stationarity status of the variables using Phillip Perron (PP) unit root testing for determining level of integration.

Phillip Perron (PP) is more robust in ways it deals with serial correlation and heteroskedasticity through NeweyWest covariance matrix estimator (Phillip \& Perron, 1988). Thus, $\mathrm{PP}$ is specified as:

$$
\Delta \Psi_{\mathfrak{t}}=\beta ! D_{\mathfrak{t}}+\eta \Psi_{\mathfrak{t}-1}+u_{\mathfrak{t}}
$$

where $u_{t}$ is the error term from where PP corrects for serial correlation and heteroskedasticity at $\mathrm{I}(0)$ through $\mathrm{t}_{\eta}=0$ and $T_{\eta}$ denoted $Z_{\mathrm{t}}$ and $Z_{\eta}$ given as

$$
\begin{gathered}
Z_{\mathrm{t}}=\left(\frac{\dot{\eta}^{2}}{\tau^{2}}\right) \frac{1}{2} \mathfrak{\eta}=0-\frac{1}{2}\left(\frac{\tau^{2}-\dot{\eta}^{2}}{\tau^{2}}\right) \cdot\left(\frac{T \cdot S E(\dot{\eta})}{\dot{\eta}^{2}}\right) ; \\
Z_{\eta}=T \dot{\eta}-\frac{1}{2} \frac{T^{2} \cdot S E(\dot{\eta})}{\dot{\eta}^{2}}\left(\tau^{2}-\dot{\eta}^{2}\right),
\end{gathered}
$$

where the terms $\eta^{\prime 2}$ and $\tau^{2}$ are consistent estimates of the parameters.

\subsubsection{ARDL model specified}

In the general form of an ARDL $\left(p, p_{1}, p_{2} \ldots p_{n}\right)$ model to cointegration based on equation $i$, we specify

$$
\Delta \Psi_{\mathfrak{t}}=\beta_{0}+\sum_{i=1}^{n} \beta 1 \Delta \Psi_{\mathfrak{t}}-1+\sum_{i=0}^{n} \lambda 1 \Delta \chi_{\mathfrak{t}-1}+\Omega_{1} \Psi_{\mathfrak{t}-1}+
$$$$
\Omega_{n} \chi_{t-1}+\mu_{t} \ldots
$$

where: $\sum_{i=1}^{n} \beta 1 \Delta \Psi_{\mathfrak{t}}-1+\sum_{i=0}^{n} \lambda 1 \Delta \chi_{\mathfrak{t}-1}$ is the short run model and $\Omega_{1} \Psi_{t-1}+\Omega_{n} \chi_{t-1}$ is the long run model of the equation. That is, $\beta_{1} \ldots \lambda_{1}$ are the short-run coefficients of the model; while ' $\Omega_{1} \ldots \Omega_{n} \ldots$ are the ARDL long-run coefficients and $\mu_{\square}$ is white noise term.

Similarly, in the event that a long run relationship is established in the model, it is idea that we correct for the error term of the residual with their respective lag specifications. This informs us about the speed of adjustment to equilibrium. Thus, error correction mechanism (ECT) is specified thus;

$$
\begin{gathered}
\mathrm{ECM}=\Delta \Psi_{\mathfrak{t}}=\beta_{0}+\sum_{i=1}^{n} \beta 1 \Delta \Psi_{\mathfrak{l}}-1+\sum_{i=0}^{n} \lambda 1 \Delta \chi \mathrm{l}-1+ \\
\Omega \mathrm{z}_{\mathrm{t}-1}+\mu_{\mathrm{t}} \ldots,
\end{gathered}
$$

here, the ECT (' $\left.\Omega z_{t-1}\right)$ replaces the $\Omega_{1} \Psi_{\mathfrak{t}-1}+{ }^{\prime} \Omega_{n} \chi_{\mathfrak{t}-1}$ in the ARDL model so that its residuals revert back to error correction model.

\subsubsection{WALD test}

The study specified the Wald test coefficient diagnostic as follows:

$\mathrm{H}_{0}: \varphi_{1}=\varphi_{2}=0$ (indicate the absence of long-run relationship)

$\mathrm{H}_{1}: \varphi_{1} \neq \varphi_{2} \neq 0$ (indicate the presence of long-run relationship),

when the coefficients of the long-run equation estimation are performed, the significant of the series is confirmed using the Wald Test coefficient diagnostic (Pesaran et al. 2001). In this case, the F-statistics of the Wald result is compared with the asymptotic lower I(0) and upper I(1) critical value bounds table to determine the significant status of the series. Whenever the value of the F-statistics falls below the lower bound value we accept $\mathrm{H}_{0}$ but if it falls above the upper bound value the $\mathrm{H}_{1}$ is accepted.

\section{Findings and discussion}

To check for the level of stationarity of the series, the study conducted the unit root test using Phillip Peron (PP) unit 
Table 1. Phillips Peron (PP) Unit Root test results (source: e-views output 2019)

\begin{tabular}{|c|c|c|c|c|}
\hline & Critical Values & PP & Prob & Order \\
\hline $\mathrm{D}(\mathrm{RGDP})$ & $\begin{array}{c}1 \%=-2.630762 \\
5 \%=-1.950394 \\
10 \%=-1.611202\end{array}$ & 4.841110 & 1.0000 & $1(0)$ \\
\hline $\mathrm{D}(\mathrm{OP})$ & $\begin{array}{c}1 \%=-2.632688 \\
5 \%=-1.950687 \\
10 \%=-1.611059\end{array}$ & -9.679957 & 0.0000 & $\mathrm{I}(1)$ \\
\hline $\mathrm{D}($ Cocoa $)$ & $\begin{array}{c}1 \%=-2.632688 \\
5 \%=-1.950687 \\
10 \%=-1.611059\end{array}$ & -7.329631 & 0.0000 & $\mathrm{I}(1)$ \\
\hline $\mathrm{D}$ (Gnts) & $\begin{array}{r}1 \%=-2.630762 \\
5 \%=-1.950394 \\
10 \%=-1.611202\end{array}$ & -4.819230 & 0.0000 & $\mathrm{I}(0)$ \\
\hline $\mathrm{D}$ (Fishery) & $\begin{array}{c}1 \%=-2.632688 \\
5 \%=-1.950687 \\
10 \%=-1.611059\end{array}$ & -7.639133 & 0.0000 & $\mathrm{I}(1)$ \\
\hline $\mathrm{D}$ (Poultry) & $\begin{array}{l}1 \%=-2.632688 \\
5 \%=-1.950687 \\
10 \%=-1.611059\end{array}$ & -7.542448 & & $\mathrm{I}(1)$ \\
\hline $\mathrm{D}$ (Cattle) & $\begin{array}{c}1 \%=-2.632688 \\
5 \%=-1.950687 \\
10 \%=-1.611059\end{array}$ & -11.74498 & 0.0000 & $\mathrm{I}(1)$ \\
\hline D(Roots_Tubers) & $\begin{array}{l}1 \%=-2.632688 \\
5 \%=-1.950687 \\
10 \%=-1.611059\end{array}$ & -7.058861 & 0.000 & $\mathrm{I}(1)$ \\
\hline
\end{tabular}

root test. The PP test result in table 1 shows that the series is stationary at different order. Real gross domestic product (RGDP) and finance provision to groundnuts (Gnts) became stationary at $\mathrm{I}(0)$ respectively. However, finance provision to oil palm (OP), cocoa, fishery, poultry, cattle and roots, and tubers, became stationary after I(1). By implication and as asserted by Pesaran and Shin (1999), Pesaran et al. (2001), supported in Onoja et al. (2017); autoregressive distributed lag (ARDL) test will be sufficient to determine the short-run and long-run cointegration relationship irrespective of whether series is of $\mathrm{I}(0)$ or $\mathrm{I}(1)$ but not $\mathrm{I}(2)$.

\subsection{Lag selection}

The study proceeded to determine the optimum lag using the vector autoregression unrestricted lag selection criteria. A possible avoidance of serial correlation, autocorrelation and heteroskedasticity and making series conform to standardized stochastic term informed this approach (Nkoro and Uko 2016) Table 2 above shows that LR-lag(-1), $\operatorname{FPE}(-1), \mathrm{AIC}(-1), \mathrm{SC}(-1)$ and $\mathrm{HQ}(-1)$ is common to all lags selection criterion hence, the system used $\operatorname{lag}(-1)$ in the analysis.

Table 2. VAR lag order selection criteria (source: e-views output 2019)

\begin{tabular}{|c|c|c|c|c|c|c|}
\hline \multicolumn{7}{|c|}{ Endogenous variables: D(RGDP) } \\
\hline \multicolumn{7}{|c|}{ Exogenous variables: C D(OP) D(COCOA) D(GNTS) D(FISHERY) D(POULTRY) D(CATTLE) D(ROOTS__TUBBERS) } \\
\hline Lag & $\log L$ & LR & FPE & AIC & SC & HQ \\
\hline 0 & -282.6126 & NA & 2636216 & 17.61288 & 17.97567 & 17.73495 \\
\hline 1 & -272.8198 & $14.24409^{*}$ & $1553888 .^{*}$ & $17.07999^{*}$ & $17.48813^{*}$ & $17.21731^{\star}$ \\
\hline 2 & -272.8193 & 0.000710 & 1660003. & 17.14056 & 17.59405 & 17.29315 \\
\hline 3 & -272.6235 & 0.261095 & 1754867. & 17.18930 & 17.68814 & 17.35714 \\
\hline
\end{tabular}

* indicates lag order selected by the criterion; LR: sequential modified LR test statistic (each test at 5\% level); FPE: Final prediction error; AIC: Akaike information criterion; SC: Schwarz information criterion; HQ: Hannan-Quinn information criterion. 
Table 3. Over-parameterized model (source: e-views output 2019)

\begin{tabular}{|c|c|c|c|c|}
\hline Variable & Coefficient & Std. Error & t-Statistic & Prob. \\
\hline $\mathrm{C}$ & -1356.427 & 1331.436 & -1.018770 & 0.3218 \\
\hline $\mathrm{D}(\operatorname{RGDP}(-1))$ & 0.377463 & 0.274118 & 1.377006 & 0.1854 \\
\hline $\mathrm{D}(\mathrm{OP}(-1))$ & -0.008619 & 0.079004 & -0.109092 & 0.9143 \\
\hline $\mathrm{D}(\operatorname{COCOA}(-1))$ & 0.000935 & 0.052253 & 0.017884 & 0.9859 \\
\hline $\mathrm{D}(\mathrm{GNTS}(-1))$ & 0.037726 & 0.123970 & 0.304315 & 0.7644 \\
\hline $\mathrm{D}(\operatorname{FISHERY}(-1))$ & 0.004907 & 0.039127 & 0.125413 & 0.9016 \\
\hline D(POULTRY $(-1))$ & -0.001427 & 0.013047 & -0.109383 & 0.9141 \\
\hline $\mathrm{D}(\mathrm{CATTLE}(-1))$ & 0.001534 & 0.035684 & 0.042992 & 0.9662 \\
\hline $\begin{array}{l}\mathrm{D}(\mathrm{ROOTS} \\
\text { TUBBERS }(-1))\end{array}$ & $-1.80 \mathrm{E}-06$ & 0.002019 & -0.000891 & 0.9993 \\
\hline $\operatorname{RGDP}(-1)$ & 0.102928 & 0.077602 & 1.326360 & 0.2013 \\
\hline $\mathrm{OP}(-1)$ & 0.032287 & 0.100695 & 0.320647 & 0.7522 \\
\hline $\operatorname{COCOA}(-1)$ & -0.019893 & 0.020939 & -0.950033 & 0.3547 \\
\hline GNTS(-1) & -0.007752 & 0.183848 & -0.042165 & 0.9668 \\
\hline FISHERY $(-1)$ & 0.004579 & 0.025822 & 0.177341 & 0.8612 \\
\hline POULTRY $(-1)$ & -0.003889 & 0.006294 & -0.617982 & 0.5443 \\
\hline CATTLE $(-1)$ & -0.007729 & 0.042257 & -0.182912 & 0.8569 \\
\hline $\begin{array}{l}\text { ROOTS } \\
\text { TUBBERS }(-1)\end{array}$ & -0.000251 & 0.003100 & -0.081120 & 0.9362 \\
\hline R-squared & 0.818358 & & Mean dependent var & 1528.740 \\
\hline Adjusted R-squared & 0.656898 & & S.D. dependent var & 1519.341 \\
\hline S.E. of regression & 889.9522 & & Akaike info criterion & 16.72666 \\
\hline Sum squared resid & 14256268 & & Schwarz criterion & 17.48212 \\
\hline Log likelihood & -275.7166 & & Hannan-Quinn criter. & 16.98745 \\
\hline F-statistic & 5.068502 & & Durbin-Watson stat & 2.018267 \\
\hline Prob(F-statistic) & 0.000712 & & & \\
\hline
\end{tabular}

\subsection{ARDL Model 1 Short-run model}

Table 3 above indicates the result of the Autoregressive distributed lag (ARDL) - over-prameterized regression for the series in the short run estimate using lag $(-1)$ as specified in the lag selection criterion. The coefficient of the variables shows seventeen estimates both for the short and the long run series in the system, that is, $c=-1356.427$; c d(RGDP(-1)), d(op(-1)), d(cocoa(-1)), d(gnts(-1)), $\mathrm{d}($ fishery $(-1))$, d(poultry $(-1))$, $\mathrm{d}($ cattle $(-1))$ and $\mathrm{d}$ (roots_ tubbers $(-1))$ through to their long run coefficients at RGDP(-1), (OP(-1), (cocoa $(-1)$, (Gnts $(-1)$, (fishery $(-1)$, (Poultry $(-1)$, (cattle $(-1)$; and (Roots_tubbers $(-1)$ with corresponding probabilities. The series shows that none of the variable is statistically significant individually in its short run as indicated by their respective probabilities. This result is a sharpe contrast to that of Ayeomoni and Aladejana (2016) whose findings revealed significant relationship between credit to agricultural sector and economic growth.

\subsection{Coefficient diagnostic}

Having conducted the short run ARDL model and checked for coefficient with insignificant probabilities, the study confirmed the presence of serial correlation of the series. And from the F-statistics $=0.4784$, the null hypothesis of no serial correlation is not rejected having fall above the 0.05 percent significant level. By implication and as indicated by the result in Table 4, we conclude that there is no serial correlation in the series. The essence of determining the presence of serial correlation is to know the fitness of the model to avoid working with spurious regression.

Table 4. Breusch-Godfrey Serial Correlation LM Test (source: e-views output 2019)

\begin{tabular}{|c|c|c|c|}
\hline F-statistic & 0.525352 & Prob. F $(1,17)$ & 0.4784 \\
\hline Obs $^{\star}$ R-squared & 1.049184 & Prob. Chi-Square $(1)$ & 0.3057 \\
\hline
\end{tabular}




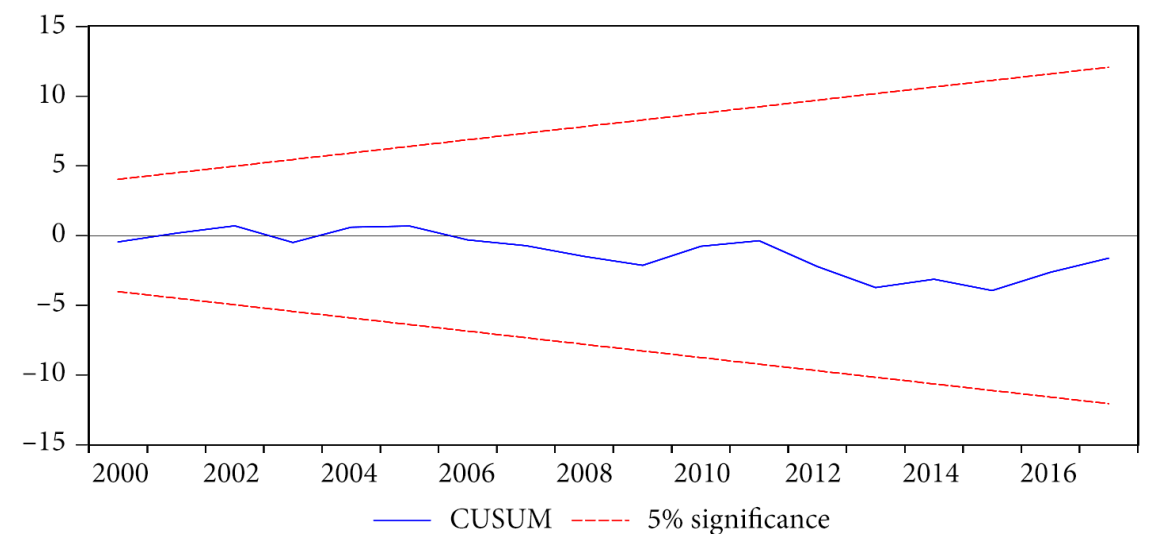

Figure 1. CUSUM Test for model stability (source: e-views output 2019)

\subsection{Stability testing}

Having confirmed the absence of no serial correlation of the series, the study went further to test for the stability of the variables and the model using the cumulative sum (CUSUM) test through recursive estimates of ordinary least square OLS). The CUSUM test helps to confirm change detection of the series, whether the variables have wondered arbitrary award from the bound line, as such, monitor the change with a corresponding 0.05 percent level of significance. If the series fall outside the bound line, then it means it is insignificant and the model is not stable otherwise it is stable. From Figure 1, the series falls within the bound line hence, it is statistically significant and a proof of the model stability.

\subsection{Wald test}

In Table 5, the long-run significant of the series were further checked using the Wald test to determine whether the study's null hypothesis of no long-run relationship jointly between $c(10), c(11), c(12), c(13), c(14), c(15), c(16), c(17)$ is true or whether they are indeed equal to zero. Unlike in model diagnostic where F-statistic is checked against its corresponding probability, the F-statistic in Wald Test is checked against its bounds critical value table (Pesaran et al. 2001). So, it does not matter whether the Wald table probability is significant or not, Bounds critical value table is used as a determinant (Pesaran et al. 2001, Nkoro and Uko 2016, Onoja et al. 2017). Accordingly, a figure below a certain Bounds critical value I0 (i.e. 0.100, 0.050, 0.025 and 0.010 ) is checked against that above I1 Bound value to determine the significance of the variables jointly in the long run. Thus, the long run significant relationship between real gross domestic product (RGDP) and guaranteed finance to oil palm, cocoa, groundnuts, fishery, poultry, cattle and, roots and tubers (as in c(14) through c(17)) as indicated by F-statistic $=0.663$ is determined under lag $(-1)$, no intercept and no trend Bound 0.050 percent level. Hence, this
Table 5. Wald Test (source: e-views output 2019)

\begin{tabular}{|c|c|c|c|}
\hline \multicolumn{3}{|c|}{ Equation: Untitled } & \multirow[b]{2}{*}{ Probability } \\
\hline Test Statistic & Value & df & \\
\hline F-statistic & 0.663342 & $(8,18)$ & 0.7165 \\
\hline Chi-square & 5.306739 & 8 & 0.7243 \\
\hline \multicolumn{4}{|c|}{$\begin{array}{l}\text { Null Hypothesis: } \mathrm{C}(10)=\mathrm{C}(11)=\mathrm{C}(12)=\mathrm{C}(13)=\mathrm{C}(14)= \\
\mathrm{C}(15)=\mathrm{C}(16)=\mathrm{C}(17)=0\end{array}$} \\
\hline \multicolumn{3}{|c|}{ Null Hypothesis Summary: } & \\
\hline \multicolumn{2}{|c|}{ Normalized Restriction $(=0)$} & Value & Std. Err. \\
\hline \multicolumn{2}{|c|}{$\mathrm{C}(10)$} & 0.102928 & 0.077602 \\
\hline \multicolumn{2}{|c|}{$\mathrm{C}(11)$} & 0.032287 & 0.100695 \\
\hline \multicolumn{2}{|c|}{$\mathrm{C}(12)$} & -0.019893 & 0.020939 \\
\hline \multicolumn{2}{|c|}{$\mathrm{C}(13)$} & -0.007752 & 0.183848 \\
\hline \multicolumn{2}{|c|}{$\mathrm{C}(14)$} & 0.004579 & 0.025822 \\
\hline \multicolumn{2}{|c|}{$\mathrm{C}(15)$} & -0.003889 & 0.006294 \\
\hline \multicolumn{2}{|c|}{$\mathrm{C}(16)$} & -0.007729 & 0.042257 \\
\hline \multicolumn{2}{|c|}{$\mathrm{C}(17)$} & -0.000251 & 0.003100 \\
\hline
\end{tabular}

table at lower $\mathrm{I} 0=2.72$ and $\mathrm{I} 1 \mathrm{Bound}=3.83$, shows that the study F-statistics 0.633 falls below I0 bound critical value hence, the null hypothesis of no long-run relationship of the series is therefore accepted. Conversely this time, this result corroborates that of Ayeomoni and Aladejana (2016) long-run estimates of no significant relationship between guaranteed finance to agriculture and real gross domestic product, in spite of model stability and correctly negatively signed error correction mechanism ect $(-1)$ (see Appendix II).

\section{Conclusions}

From the findings of the results, it is clear that agricultural guaranteed finance provision to nominated agricultural production - oil palm, cocoa, groundnuts, fishery, poultry, cattle, roots, and tubers is statically insignificant both at the short-run and at the long-run level. This result was 
also confirmed by the Wald test bound critical table, which shows that the Wald result falls below the lower bound I $(0)$ critical bound table value hence, the null hypothesis that $\mathrm{H}_{0}$ is not rejected is accepted.

\section{Recommendations}

Based on the findings of the study and the conclusion, specific recommendations must be suggested. Thus, the study suggests an increased finance provision to agriculture especially to the listed agriculture productions of the study and; to make deliberate efforts at determining which of the agricultural finance provision yield the most contributory impact on economic growth.

\section{Acknowledgements}

The authors deeply appreciate Covenant University management for the sponsorship of this research article.

\section{References}

Adesina JO, Graham Y, Olukoshi A (2006) Africa and Development Challenges in the New Millennium: The NEPAD debate. In: Adesina JO, Graham Y, Olukoshi A (Ed). London and New York: Zed Books, Pretoria: UNISA Press, in association with CODESRIA, Dakar.

Ayeomoni IO, Aladejana SA (2016) Agricultural credit and economic growth Nexus. Evidence from Nigeria. International Journal of Academic Research in Accounting, Finance, and Management 6 (2): 146-158. https://doi.org/10.6007/IJARAFMS/v6-i2/2099

Ewetan O, Fakile A, Urhie E, Oduntan E (2017) Agricultural output and economic growth in Nigeria. Journal of African Research in Business \& Technology 2017: 1-11. https://doi.org/10.5171/2017.516093

Hartarska V, Nadolnyak D, Shen X (2015) Agricultural credit and economic growth in ruralareas. Agricultural Finance Review 75 (3): 302-312. https://doi.org/10.1108/AFR-04-2015-0018

Ijaiya MA, Sanni M, Amujo ET (2016) Agricultural credit guarantee scheme fund: Tool for Economic growth in Nigeria. Osogbo Journal of Management 1 (3): 20-33.

Isibor A, Olokoyo F, Arogundade M, Osuma G, Ndigwe C (2018) Exchange rate management and sectoral output performance. International Journal of Supply Chain Management 7 (5): $129-134$

Manyong VM, Ikpi A, Olayemi JK, Yusuf SA, Omonona R, Idachaba FS (2003) Agriculture in Nigeria: identifying opportunities for increased commercialization and investment. USAID/Nigeria Main report from International Institute of Tropical Agriculture (IITA) and University of Ibadan.

Nkoro E, Uko AK (2016) Autoregressive Distributed Lag (ARDL) cointegration technique: Application and interpretation. Journal of Statistical and Econometric Methods 5 (4): 63-91.

Obansa SAJ, Maduekwe IM (2013) Agriculture financing and economic growth in Nigeria. European Scientific Journal 9 (1): 168-204.
Oboh VU, Ekpebu ID (2011) Determinants of formal agricultural credit allocation to the farm sector by arable crop farmers in benue state, Nigeria. African Journal of Research 6 (1): 181-185.

Okunlola FA (2013) Public sector investment in agriculture: structure and influence on Nigerian economy (1970-2010). An MBA Thesis submitted to the Department of Finance and Banking, University of Port Harcourt.

Okunlola FA (2014) NEXIM Bank and Export Promotion: Theory and Evidence. An MSC thesis submitted to the Department of Finance and Banking, University of Port Harcourt.

Okunlola FA, Oke JA (2018) Agricultural finance, agriculture value added and diversification growth panacea: an economy comparison. Peer Review Proceeding $4^{\text {th }}$ Annual International Academic Conference on Accounting and Finance organized by The Institute of Chartered Accountants of Nigeria held at Covenant University on April 18-20, 2018.

Omilola F, Lambert (2009) Public spending on Agriculture in Africa: trends and composition. ReSAKSS Working Paper o. 28, April 2009.

Omankhanlen AE (2013) Agricultural investment risk relationship to national domestic production. International Journal of Risk and Contingency Management (IJRCM) 2 (2): 80-98. https://doi.org/10.4018/ijrcm.2013040105

Omorokunwa OG, Obadiaru ED (2016) Credit constraint and agricultural output in Nigeria. Sokoto Journal of the Social Sciences 6 (1): 172-185.

Onoja AO, Achike AI, Ajibade TB (2017) Econometric analysis of Short-run and Long-run determinants of agricultural value addition in Africa. Agrosearch 17 (1): 26-43. https:// doi.org/10.4314/agrosh.v17i1.3

Osuma GO, Babajide AA, Ikpefan OA, Nwuba E B, Jegede PW (2019) Effects of global decline in oil price on the financial performance of selected deposit money banks in Nigeria. International Journal of Energy Economics and Policy 9 (3): 187-195. https://doi.org/10.32479/ijeep.7514

Osuma G, Ikpefan A, Osabohien R, Chisom N, Pascal N (2018) Working capital management and bank performance: empirical research of ten deposit money banks in Nigeria. Banks and Bank Systems 13 (2): 49-61. https://doi.org/10.21511/bbs.13(2).2018.05

Oyakhilomen O, Zibah RG (2014) Agricultural Production and Economic Growth in Nigeria: Implication for Rural Poverty Alleviation. Quarterly Journal of International Agriculture 54 (3): 207-223.

Pesaran H, Shin Y (1999) An autoregressive distributed lag modeling approach to cointegration analysis. In: Strom S (ed). Econometrics and Economic Theory in the 20th Century: The Ragnar Frisch Centennial Symposium. Cambridge University Press: Cambridge.

Pesaran MH, Shin Y, Smith RJ (2001) Bounds testing approaches to the analysis of level relationships. Journal of Applied Econometrics 16: 289-326. https://doi.org/10.1002/jae.616

Phillips PCB, Perron P (1988) Testing for Unit Roots in time series regression. Biometrika (75): 335-346.

https://doi.org/10.1093/biomet/75.2.335

Sertoğlu K, Ugural U, Bekun FV (2017) The contribution of agricultural sector on economic growth of Nigeria. International Journal of Economics and Financial Issues 7 (1): 547-552. 


\section{APPENDIX I}

Guaranteed finance to agricultural produce and real gross domestic products

\begin{tabular}{|c|c|c|c|c|c|c|c|c|}
\hline & RGDP & Op & Cocoa & GNts & Fishery & Poultry & Cattle & Roots \& Tubers \\
\hline 1981 & 15258 & 39.0 & 20.3 & 480.9 & - & $20,802.9$ & $3,297.4$ & $1,358.8$ \\
\hline 1982 & 14985 & 496.5 & 7.0 & 12.0 & 39.6 & $20,345.1$ & 446.8 & 785.9 \\
\hline 1983 & 13849.7 & 76.2 & 92.6 & 55.6 & $1,575.0$ & $20,167.4$ & 587.7 & $2,344.5$ \\
\hline 1984 & 13779.3 & 70.0 & 83.1 & 87.9 & 826.0 & $10,702.1$ & 919.6 & 227.5 \\
\hline 1985 & 14953.9 & $1,154.3$ & 38.2 & 71.8 & 718.1 & $11,365.1$ & $1,516.7$ & $2,180.2$ \\
\hline 1986 & 15237.9 & 252.0 & 29.5 & 605.2 & $1,644.7$ & $20,535.8$ & $3,102.9$ & $2,353.6$ \\
\hline 1987 & 15263.9 & $2,724.5$ & $1,206.6$ & $1,569.8$ & $4,526.3$ & $21,078.7$ & $4,368.1$ & $13,494.1$ \\
\hline 1988 & 16215.4 & 701.0 & $1,282.7$ & $3,287.4$ & $4,536.8$ & $10,848.5$ & $3,622.5$ & $15,697.4$ \\
\hline 1989 & 17294.7 & $1,062.0$ & $2,676.5$ & $1,724.5$ & $4,538.7$ & $4,675.7$ & $2,230.8$ & $31,007.5$ \\
\hline 1990 & 19305.6 & 175.0 & 575.3 & $1,882.3$ & $3,900.7$ & $3,127.1$ & $1,334.4$ & $21,798.2$ \\
\hline 1991 & 19199 & 116.0 & 578.5 & $1,273.8$ & $1,698.2$ & $1,559.7$ & $2,532.5$ & $14,412.9$ \\
\hline 1992 & 19620.2 & 243.0 & 902.0 & $1,293.8$ & $1,038.7$ & $4,022.7$ & 801.5 & $11,880.2$ \\
\hline 1993 & 19927.99 & 160.0 & 578.0 & 815.4 & 428.0 & $3,314.3$ & $2,081.5$ & $13,619.6$ \\
\hline 1994 & 19979 & 7.5 & 220.3 & $2,562.8$ & $2,438.0$ & $4,007.4$ & $5,362.5$ & $9,973.5$ \\
\hline 1995 & 20353.2 & 450.3 & 708.0 & $2,953.5$ & $1,512.0$ & $10,287.5$ & $6,564.0$ & $14,453.1$ \\
\hline 1996 & 21177.9 & 485.0 & $2,425.0$ & $3,698.0$ & $2,145.0$ & $13,867.5$ & $9,033.4$ & $20,126.4$ \\
\hline 1997 & 21789 & $4,122.5$ & $1,510.0$ & $2,172.0$ & $3,554.5$ & $13,157.4$ & $6,084.0$ & $35,479.0$ \\
\hline 1998 & 22332.8 & 442.5 & 502.0 & $1,135.3$ & $3,456.0$ & $13,189.0$ & $6,554.9$ & $35,613.0$ \\
\hline 1999 & 22449.4 & 382.0 & 770.0 & $2,796.0$ & $6,180.0$ & $7,447.0$ & $2,504.0$ & $57,920.5$ \\
\hline 2000 & 23688.3 & $1,060.0$ & 435.0 & $2,123.0$ & 899.0 & $19,041.0$ & $3,318.0$ & $81,500.0$ \\
\hline 2001 & 25267.54 & $4,602.5$ & $1,579.0$ & $3,192.5$ & $15,742.2$ & $49,440.7$ & $1,650.0$ & $191,410.3$ \\
\hline 2002 & 28957.7 & $4,427.5$ & $1,100.0$ & $6,826.9$ & $12,069.3$ & $44,943.0$ & $10,655.0$ & $296,906.1$ \\
\hline 2003 & 31709.5 & $3,380.0$ & $1,971.0$ & $3,030.0$ & $13,050.0$ & $89,133.0$ & $4,637.4$ & $351,687.5$ \\
\hline 2004 & 35020.5 & $7,320.0$ & $2,960.0$ & $3,025.0$ & $18,240.0$ & $170,199.0$ & $8,770.0$ & $558,235.0$ \\
\hline 2005 & 37474.9 & $78,075.0$ & $52,375.0$ & $23,160.0$ & $262,195.0$ & $719,270.5$ & $48,612.3$ & $3,201,556.1$ \\
\hline 2006 & 39995.5 & $37,290.0$ & $18,465.0$ & $11,080.0$ & $114,400.0$ & $303,451.0$ & $25,290.0$ & $1,362,532.3$ \\
\hline 2007 & 42922.41 & $18,450.0$ & $21,040.0$ & $1,866.0$ & $140,690.0$ & $298,599.3$ & $21,145.0$ & $1,477,946.8$ \\
\hline 2008 & 46012.5 & $109,344.0$ & $62,680.0$ & $17,465.0$ & $368,630.0$ & $821,280.8$ & $190,541.0$ & $1,193,003.0$ \\
\hline 2009 & 49856 & $142,731.6$ & $81,780.0$ & $10,240.0$ & $708,621.2$ & $922,608.1$ & $531,852.6$ & $1,728,474.6$ \\
\hline 2010 & 54612.3 & $62,338.0$ & $22,862.0$ & $8,440.0$ & $461,128.0$ & $854,313.5$ & $265,252.0$ & $1,722,875.0$ \\
\hline 2011 & 57511 & $81,940.0$ & $10,265.0$ & $16,324.9$ & $589,667.5$ & $1,495,588.4$ & $204,000.0$ & $2,455,811.5$ \\
\hline 2012 & 59929.9 & $275,520.0$ & $121,739.1$ & $10,985.0$ & $378,311.9$ & $1,349,838.5$ & $248,243.3$ & $3,449,112.2$ \\
\hline 2013 & 63218.7 & $107,625.0$ & $25,563.0$ & $8,350.0$ & $371,403.0$ & $1,134,092.5$ & $486,616.0$ & $3,229,817.5$ \\
\hline 2014 & 67152.8 & $159,602.0$ & $218,034.0$ & $103,820.0$ & $453,089.2$ & $1,868,877.9$ & $163,590.0$ & $3,560,581.1$ \\
\hline 2015 & 69023.9 & $123,790.0$ & $271,230.0$ & $5,030.0$ & $485,089.2$ & $1,134,092.5$ & $52,260.0$ & $4,567,382.3$ \\
\hline 2016 & 67931.2 & $124,610.0$ & $320,450.0$ & $15,955.0$ & $444,763.0$ & $860,413.0$ & $81,450.0$ & $3,932,627.8$ \\
\hline 2017 & 68490.9 & $160,295.0$ & $329,750.0$ & $28,640.0$ & $387,640.0$ & $572,476.0$ & $38,180.0$ & $2,406,835.4$ \\
\hline
\end{tabular}


APPENDIX II

\begin{tabular}{|c|c|c|c|c|}
\hline \multicolumn{5}{|c|}{ Error Correction Model (ECT $(-1)$} \\
\hline \multicolumn{5}{|l|}{ Dependent Variable: RESID } \\
\hline \multicolumn{5}{|l|}{ Method: Least Squares } \\
\hline \multicolumn{5}{|l|}{ Date: 07/17/19 Time: $22: 45$} \\
\hline \multicolumn{5}{|l|}{ Sample: 19832017} \\
\hline \multicolumn{5}{|l|}{ Included observations: 35} \\
\hline \multicolumn{5}{|c|}{ Presample missing value lagged residuals set to zero. } \\
\hline Variable & Coefficient & Std. Error & $\mathrm{t}$-Statistic & Prob. \\
\hline $\mathrm{C}$ & -142.7766 & 271.3998 & -0.526075 & 0.6039 \\
\hline $\mathrm{D}(\operatorname{RGDP}(-1))$ & 0.107686 & 0.167807 & 0.641723 & 0.5274 \\
\hline $\mathrm{D}(\mathrm{OP}(-1))$ & 0.001490 & 0.008297 & 0.179604 & 0.8590 \\
\hline $\mathrm{D}(\mathrm{COCOA}(-1))$ & -0.001283 & 0.010846 & -0.118284 & 0.9069 \\
\hline $\mathrm{D}(\mathrm{GNTS}(-1))$ & 0.000417 & 0.021262 & 0.019618 & 0.9845 \\
\hline D(FISHERY $(-1))$ & $-6.33 \mathrm{E}-05$ & 0.004617 & -0.013704 & 0.9892 \\
\hline D(POULTRY $(-1))$ & -0.000165 & 0.002710 & -0.061018 & 0.9519 \\
\hline D(CATTLE $(-1))$ & -0.000198 & 0.003447 & -0.057410 & 0.9547 \\
\hline $\mathrm{D}$ (ROOTS__TUBBERS(-1)) & -0.000126 & 0.000388 & -0.325272 & 0.7479 \\
\hline ECT $(-1)$ & -0.010366 & 0.045636 & -0.227150 & 0.8223 \\
\hline $\operatorname{RESID}(-1)$ & -0.329679 & 0.271145 & -1.215877 & 0.2364 \\
\hline R-squared & 0.074438 & \multicolumn{2}{|c|}{ Mean dependent var } & $-3.25 \mathrm{E}-15$ \\
\hline Adjusted R-squared & -0.368222 & \multicolumn{2}{|c|}{ S.D. dependent var } & 712.5399 \\
\hline S.E. of regression & 833.4652 & \multicolumn{2}{|c|}{ Akaike info criterion } & 16.55492 \\
\hline Sum squared resid & 15977278 & \multicolumn{2}{|c|}{ Schwarz criterion } & 17.08818 \\
\hline Log likelihood & -277.7111 & \multicolumn{2}{|c|}{ Hannan-Quinn criter. } & 16.73900 \\
\hline F-statistic & 0.168160 & \multicolumn{2}{|c|}{ Durbin-Watson stat } & 1.904544 \\
\hline Prob(F-statistic) & 0.998066 & & & \\
\hline
\end{tabular}

